\title{
Monitoring the sprouting process of wheat by non-conventional approaches
}

Silvia Grassi, Gaetano Cardone, Davide Bigagnoli, Alessandra Marti*

Department of Food, Environmental, and Nutritional Sciences (DeFENS), Università degli Studi di Milano, via G. Celoria 2, 20133 Milan, Italy

* Corresponding author:

E-mail address: alessandra.marti@unimi.it

Address: via G. Celoria 2, 20133 Milan, Italy 


\begin{abstract}
Controlled wheat sprouting is a useful process to achieve the perfect balance between nutritional advantages and technological performance. This study aims at developing a methodology for evaluating wheat sprouting by using a portable NIR device directly on kernels. Wheat kernels were germinated up to $72 \mathrm{~h}$ with wet kernels being collected after 24, 36, 48, 60 and $72 \mathrm{~h}$ and analysed directly or after drying by a MicroNIR in the spectral range of 950-1650 nm. Wholegrain and refined flours from sprouted kernels were investigated for chemical composition, enzymatic activities, starch pasting properties, and gluten aggregation kinetics. Principal Component Analysis (PCA) on the whole dataset derived from chemical composition and technological analyses revealed that the main changes occurred within the first $48 \mathrm{~h}$. PCAs on spectral data, both from wet and dried kernels, assessed the effect of sprouting time, both on starch and protein fractions, as observed by conventional analyses on flour.

Thus, a NIR portable device can be implemented directly on wet kernels to determine the stage of sprouting, skipping both the drying and refinement steps. Implementing this approach could help the food industry in standardizing and monitoring the sprouting process, delivering novel cereal-based products with guaranteed and consistent characteristics.
\end{abstract}

Keywords: sprouting; pasting properties; protein aggregation; Near Infrared spectroscopy 


\section{1. Introduction}

2 Sprouting (or germination) is a traditional technique of food processing used in most African and

Asian countries to enhance nutritional properties and taste of cereals and pulses (Hübner \& Arendt, 2013).

Indeed, enzymes developed during germination degrade antinutrients, such as phytic acid and trypsin inhibitors, increasing the content and the bioavailability of nutrients, including vitamins and minerals (Hübner \& Arendt, 2013). Moreover, germination is a useful tool for improving the protein digestibility of grains, such as sorghum and millet (Annor, Tyl, Marcone, Ragaee, \& Marti, 2017; Elmaki, Babiker, \& El Tinay, 1999), thus promoting their use not only in common foods consumed in their countries of origin, but also in Western-style food formulations. On the other hand, starch digestibility generally increases after germination, due to the increased $\alpha$-amylase activity induced by the treatment (Dhital, Warren, Butterworth, Ellis, \& Gidley, 2017).

Traditionally, the germination process has been performed at home, neglecting the potential grain safety risk of the uncontrolled process. Controlling the process seems the unique way of decreasing the safety risk while preserving the other nutritional and technological benefits of the product. In this context, a germination plant was developed where grains were germinated under controlled conditions and stabilized by drying with hot air to extend product shelf-life. (Bellaio, Kappeler, Rosenfeld, \& Jacobs, 2013). Controlled germination of pulses (i.e. pea and chickpeas) induced mild structural modifications in these legumes, sufficient to reduce antinutritional factors (e.g. phytic acid), without negatively affecting their nutritional quality (e.g. starch digestibility) (Erba et al., 2018). In addition, flour from germinated chickpeas improved nutritional and rheological characteristics in enriched cereal-based foods (Marengo et al., 2017).

As regards wheat, sprouted wheat could help improve product functionality in terms of specific volume, crumb structure and softness during storage (Marti, Cardone, Pagani, \& Casiraghi, 2018), making sprouted wheat a good replacement for the enzymatic improvers that are commonly present in the formulation of baked products (Marti, Cardone, Nicolodi, Quaglia, \& Pagani, 2017). On the 
other hand, germination under uncontrolled conditions of moisture, temperature and/or time might result in high accumulations of hydrolytic enzymes that negatively affect the technological performance of flour, making it unsuitable for baked foods. This can also occur directly in the field (e.g. pre-harvest sprouting), when grains are exposed to prolonged wet or foggy conditions just prior to ripening for harvest.

In this context, controlling the germination process seems the only way of enhancing nutritional and sensory benefits while optimizing flour performance to ensure a satisfactory and consistent product. Different methods have been proposed for characterizing pre-harvest sprouted wheat (e.g. falling number, stirring number). Both use the natural starch present in ground grain as substrate, neglecting the effect of hydrolytic enzymes (such as protease). Indeed, samples with similar falling/stirring number values can be quite different in composition (Kruger, 1994). Near Infrared Spectroscopy has proved to be successful in determining the authenticity and traceability of cereals (Cozzolino, 2014). Moreover, Infrared spectroscopy has been applied on flour to detect pre-harvest sprouting and the time of its occurrence in wheat and barley (Burke et al., 2016). Burke et al. (2016) obtained good Partial Least Squares models for FT-IR data $\left(\mathrm{R}_{\mathrm{CV}}{ }^{2}\right.$ of 0.75$)$, but poor validation results by FT-NIR modelling as high overfitting occurred. As for the development of individual kernels, a review by Fox \& Manley (2014) described in detail how Near Infrared Spectroscopy is used to evaluate the physical quality and chemical traits of cereal grains. For even closer examination, Near- Infrared Hyperspectral Imaging combined with different discriminant classification techniques proved to be a useful tool to classify sprouted, midge-damaged and healthy wheat kernels with excellent accuracy (98.3\%) (Singh, Jayas, Paliwal, \& White, 2009). However, lack of information on the relation between wheat functionality and hyperspectral images makes it difficult to draw any conclusions useful for the technological development of robust simplified and cost effective spectroscopic systems. Indeed, the current interest in Near Infrared spectroscopy is the development of handheld devices which are recognized as user-friendly as well as faster and 
cheaper than benchtop instruments but just as reliable as these latter for customized applications (Grassi, Casiraghi, \& Alamprese, 2018).

Taking into consideration the limitations of the conventional methods for measuring wheat sprouting and the potential of sprouting process under controlled conditions, this study aimed at filling the gap between sprouting conditions, kernel characteristics and product functionality, by monitoring wheat sprouting under controlled conditions. In particular, changes on both starch and protein features during the germination process were assessed by both conventional and innovative (e.g. rapid, non-destructive, in-line) approaches.

\section{Materials and methods}

\subsection{Materials}

Common wheat (Bologna cv; CTRL; protein: $13.3 \mathrm{~g} / 100 \mathrm{~g} \mathrm{db}$ ) was germinated in a pilot plant (Memmert GmbH Co. KG, Schwabach, Germany) at Molino Quaglia (Molino Quaglia S.p.A., Vighizzolo d'Este, Italy). Two batches of wheat were divided in five aliquots ( $1 \mathrm{~kg}$ each for each sprouting time under investigation, for a total number of 10 samples) which were placed in aluminium boxes $(24.5 \times 30 \times 9 \mathrm{~cm})$ and soaked in water (kernels:water ratio of 1:4 w/v) for $24 \mathrm{~h}$ at $21{ }^{\circ} \mathrm{C}$ and $90 \%$ relative humidity (RH). After soaking, samples were placed in aluminium perforated trays $(24.5 \times 30 \times 9 \mathrm{~cm})$ and germinated at $21{ }^{\circ} \mathrm{C}$ and $90 \% \mathrm{RH}$ until $72 \mathrm{~h}$. Samples were collected after soaking and after 24 h, 36 h, 42 h, 48 h, 60 h, 66 h, and 72 h of sprouting and analysed as such, as described in section 2.5. Samples collected after 24 h, 36 h, 48 h, 60 h, and 72 $\mathrm{h}$ of sprouting were dried at $50{ }^{\circ} \mathrm{C}$ for $9 \mathrm{~h}$ (Rational Self Cooking Center ${ }^{\circledR}$, Rational International AG, Mestre, VE, Italy), and analysed as reported in the following sections. Unsprouted wheat was used as control (CTRL).

An aliquot of dried kernels $(250 \mathrm{~g})$ was ground into wholemeal flour ( $<500$ microns $)$ with a laboratory mill (IKA Universalmühle M20; IKA Laborteknic, Staufen, Germany), fitted with a water cooling jacket in order to avoid overheating during grinding. Another aliquot (250 g) was 
milled into refined flour using a laboratory mill (RM 1300, Erkaya, Ankara, Turkey), equipped with a $250 \mu \mathrm{m}$ sieve.

\subsection{Enzymatic activities}

Alpha- and beta-amylase activities were determined in duplicate using the Ceralpha Method and Betamyl-3 Assay (Megazyme, Bray, Ireland), respectively. Alpha-amylase activity was also indirectly monitored by measuring the Stirring Number (SN; AACCI 22-08.01) and the Falling Number (FN; AACCI 56-81.03).

\subsection{Carbohydrates}

Total starch and damaged starch content were determined in duplicate by standard methods (AACCI 76-13.01 and AACCI 76-31.01, respectively). As regard sugars, flour (1 g) was suspended in water $(100 \mathrm{ml})$ for $60 \mathrm{~min}$ at $22^{\circ} \mathrm{C}$. After centrifugation $(10 \mathrm{~min}, 1400 \mathrm{x} \mathrm{g})$, the supernatant was used to quantify in duplicate maltose, sucrose and D-glucose using the Maltose/Sucrose/D-Glucose Assay Kit (Megazyme, Bray, Ireland).

Pasting properties were determined in duplicate using the Rapid Viscoanalyzer (RVA-4500, Perten, Sweden) according to the approved AACCI (76-21.01) method. An aliquot of sample (4 $\mathrm{g}$ for wholegrain flour and $3.5 \mathrm{~g}$ for refined flour) was dispersed in distilled water or $1 \mathrm{mM} \mathrm{AgNO}_{3}(25$ $\mathrm{ml})$, scaling both sample and water weight on a $14 \%(\mathrm{w} / \mathrm{w})$ sample moisture basis. The suspension was mixed at $160 \mathrm{rpm}$ and subjected to the following temperature profile: at $50{ }^{\circ} \mathrm{C}$ for $1 \mathrm{~min}$; then increasing to $95{ }^{\circ} \mathrm{C}$ and keeping it at that temperature for $5 \mathrm{~min}$; then letting it cool to $50{ }^{\circ} \mathrm{C}$ and keeping it at that temperature for $2 \mathrm{~min}$.

\subsection{Proteins}

Protein content was determined in duplicate by standard method (AACCI 46-30.01). Gluten aggregation properties were measured in triplicate using the GlutoPeak ${ }^{\circledR}$ (Brabender, Duisburg, Germany) according to Marti et al. (2015), using distilled water as solvent. 


\subsection{Spectra acquisition}

Spectra of both wet (after soaking, i.e. CTRL, and sprouting at 24 h, 36 h, 42 h, 48 h, 60 h, 66 h, and $72 \mathrm{~h}$ ) and dried (CTRL, $24 \mathrm{~h}, 36 \mathrm{~h}, 48 \mathrm{~h}, 60 \mathrm{~h}$, and $72 \mathrm{~h}$ ) kernels were collected using a MicroNIR OnSite (VIAVI, Santa Rosa, CA), equipped with a shaker probe (Supplementary Figure 1). Six aliquots were collected for each sample, and three spectra were acquired for each aliquot, for a total of eighteen spectra for each sample. The spectra were acquired in diffuse reflectance in the spectral range of $950-1650 \mathrm{~nm}$, with $12.5 \mu$ s of integration time and 200 scans at $80 \mathrm{~Hz}$ using the software available on the MicroNIR OnSite (VIAVI, Santa Rosa, CA).

\subsection{Data elaboration}

Analysis of variance (ANOVA) on the chemical composition and technological features was performed using the Tukey HSD test available as part of the Statgraphic Plus software (v. 5.1., StatPoint Inc., Warrenton, VA, USA).

Matlab software (v. 2016, etc.) was used to subject the same dataset to Principal Component Analysis (PCA) by Singular Value Decomposition (SVD), which results in a matrix with mean-zero unit variance columns after column autoscaling.

PCA was also performed on spectral data by means of Matlab software (v. 2016a, Mathworks, Inc., Natick, MA) after spectral pre-treatment with smoothing (Savitzky-Golay, 3 wavelengths gap size) and first derivative (Savitzky-Golay, 3 wavelengths gap size and 2nd order polynomial). Dried kernel spectra were averaged according to sampling points (CTRL, $24 \mathrm{~h}, 36 \mathrm{~h}, 48 \mathrm{~h}, 60 \mathrm{~h}, 72 \mathrm{~h}$ ). The same approach was followed for wet kernel evaluation; in this case the resultant dataset consisted of an average spectrum for each of the two separated batches for the considered sampling points (CTRL, 24 h, 36 h, 42 h, 48 h, 60 h, 66 h, 72 h). PCAs were internally validated by venetian blind cross-validation strategy. The scores obtained from PCA performed on MicroNIR data on wet kernels and dry kernels, as well as the scores from PCA on data from composition, enzymatic 
activities, starch pasting properties and gluten aggregation kinetics of wholegrain and refined flour were normalised (between 0 and 1) and modelled according to sprouting time.

\section{Results and Discussion}

\subsection{Effect of germination on chemical composition}

Starch content in wholegrain flour decreased during germination (Table 1), due to the accumulation of amylase activity. However, changes in starch content became significant only after $72 \mathrm{~h}$ of germination. Indeed, the extent of starch degradation depends upon the length of sprouting (Lorenz \& Valvano, 1981). No significant differences were observed in the amounts of starch in the refined flours. Differences in the degree of starch degradation throughout the kernel could account for the different trends observed in wholegrain and refined flours. Indeed, starch granules were more degraded near the aleurone layer and germ region, than in the inner endosperm (Faltermaier, Zarnkow, Becker, Gastl, \& Arendt, 2015), from which the refined flour is obtained. As expected, after sprouting, the amount of maltose and glucose increased, confirming previous findings (Marti et al., 2017), whereas the sucrose content decreased, especially in refined flours. Changes in sugar content might be due to the increase in enzymatic activities after sprouting (i.e. $\alpha$-amylases). The synthesis and accumulation of enzymes during the germination phase is necessary to assure the hydrolysis of macromolecules and thus to allow the growth of the embryo. The increase in protein content in wholegrain flours during germination (Table 1) might reflect the loss of dry matter, mainly in the form of carbohydrates. Indeed, as total carbohydrates decreases, the percentage of other nutrients (e.g. proteins) increases (Lorenz, Collins, \& Kulp, 1981). Data on kernel characteristics- such as test weight and 1000-kernel weight (data not shown) - confirmed the loss of matter during the germination process. The synthesis of enzymes during germination might also account for the increase in protein content (Bau, Villaume, Nicolas, \& Méjean, 1997). 
Protein content in wholegrain did not significantly change within $38-48 \mathrm{~h}$ of sprouting, likely due to a turnover of protein and non-protein nitrogen resulting in an equilibrium of the degradation and synthesis processes during germination (Bau et al., 1997). Previous studies have shown that the increase of enzymatic activities, for example, protease and amylase leads to the degradation of proteins to provide the developing plant with nutrients (Koehler, Hartmann, Wieser, \& Rychlik, 2007). Conflicting results among studies might be due to different effects of germination on seeds from different plant species, varieties or cultivars as well as variations in germination conditions (temperature, light, moisture and the time of germination) (Yang, Basu, \& Ooraikul, 2001). In refined flour, a decrease in protein content was observed as the germination proceeded, likely due to the degradation of macromolecules by enzymes. It should also be also noted that non gluten proteins are mainly located in the external layers of the grains and are removed during milling.

\subsection{Effect of germination on enzymatic activities}

The synthesis of amylases increased during germination (Table 1$)$, following a linear trend $\left(\mathrm{R}^{2}=\right.$ 0.99 for $\alpha$-amylase and $\mathrm{R}^{2}=0.79$ for $\beta$-amylase). The drying step at $50{ }^{\circ} \mathrm{C}$ - to which the germinated samples were subjected - resulted in a significant reduction of the $\beta$-amylase content (data not shown). However, the values tended to increase as germination time increased, even if a significant difference was detectable only between 24 and 38 hours (Table 1). Despite $\alpha$-amylase whose levels were very low in unsprouted wheat - $\beta$-amylase is already formed in the endosperm at seed maturity (Ziegler, 1995). Being linked to other seed proteins, $\beta$-amylase initially is only partially present in a free or soluble form. During germination, it is progressively released in a soluble form, presumably due to proteases secreted by the aleurone and/or scutellum (Ziegler, 1995).

Increase in amylase activity was confirmed by the falling and stirring number, whose values decreased as the germination time increased (Table 1). Decreasing these two indices during sprouting indicates starch degradation and/or an increase in $\alpha$-amylase activity (Lorenz \& Valvano, 
1981). Generally, increasing levels of $\alpha$-amylase result in a decrease in FN down to $60 \mathrm{~s}$, beyond which further increases in activity cannot be measured (MacArthur, D’Appolonia, \& Banasik, 2009). Our values for wholegrain flours ranged from $417 \mathrm{~s}$ and $98 \mathrm{~s}$ for CTRL and wheat after $72 \mathrm{~h}$ sprouting, respectively, in agreement with the increase in amylase activity measured during sprouting. A similar trend was observed in refined flours. A linear relationship was observed between FN and sprouting time, for both wholegrain $\left(\mathrm{R}^{2}=0.962\right)$ and refined flours $\left(\mathrm{R}^{2}=0.899\right)$. Values above $250 \mathrm{~s}$ are generally required for ranking the grain as a high-quality grade. Values below $250 \mathrm{~s}$ indicate some sprouting and higher levels of amylase enzyme (MacArthur et al., 2009).

\subsection{Effect of germination on starch pasting properties}

Germination promoted a shift of pasting temperature toward lower temperatures compared to CTRL (Fig. 1 and related data in supplementary Table 1). Drastic decreases in viscosity during heating (peak viscosity) and cooling (final viscosity) steps were also observed, indicating that swelling, gelatinization and gelation capacity of sprouted grains were drastically decreased and affected by the length of sprouting time. The greatest change in pasting properties occurred between 24 and $38 \mathrm{~h}$ of sprouting. A similar trend was also observed for refined flours (Fig. 1).

It can be generalized that peak viscosity is inversely proportional to $\alpha$-amylase activity. Starch granules lose their resistance to swelling due to higher activity of $\alpha$-amylase, and the reduced resistance to swelling in turn lowers the paste viscosity of the sprouted sprouts (Simsek et al., 2014).

It was also observed that as germination time increased to $48 \mathrm{~h}$, viscosity dropped gradually. This loss of viscosity might be related to two factors: firstly, starch granule hydrolysis by the amylases produced during sprouting and then further starch degradation by these enzymes during pasting. As pasting viscosity is dependent on the $\alpha$-amylase activity present in the samples, the $\alpha$-amylase action was blocked by adding silver nitrate, which strongly inhibited $\alpha$-amylase during the test. The addition of silver nitrate largely increased peak and end viscosity readings of flour for both CTRL 
and sprouted wheat, suggesting that even low levels of $\alpha$-amylase, such as in unsprouted wheat, lead to noticeable starch breakdown under these conditions. As regards the effect of sprouting, $\alpha-$ amylase inactivation resulted in similar RVA profiles for CTRL and sprouted wheat, indicating that the pasting and gelation properties of starch were not affected by sprouting time. Hence, the results of the present study demonstrate that the changes observed in the pasting properties of sprouted wheat were caused by starch degradation due to the action of elevated $\alpha$-amylase activities during analysis and not by inherent changes in starch swelling, pasting, and gelation properties, while significant hydrolysis of starch only occurs during subsequent processing (Olaerts et al., 2016). Results suggest that starch degradation due to $\alpha$-amylase activity did not greatly increase over sprouting time, and hence, starch in sprouted wheat grain with a FN lower than $250 \mathrm{~s}$ is still of a good quality. Similar results were found in field-sprouted grains (Olaerts et al., 2016). Furthermore, similar damaged starch levels (Table 1) in flour from CTRL and sprouted wheat at different times suggest that no incipient hydrolysis of the starch molecules as a result of the action of amylolytic enzymes had occurred during sprouting under controlled conditions. This is in line with the results from Olaerts et al. (2016) who did not detect inherent damage of starch granules during sprouting in the field.

Surprisingly, the trends for wheat after $24 \mathrm{~h}$ of sprouting were not the same as for samples sprouted for $38 \mathrm{~h}$ or more. On the other hand, in the presence of alpha-amylase inhibitor, peak viscosity of 24h sprouted sample was higher than CTRL and other sprouted kernels. This increase in viscosity may be due to changes in the kernel, leading to an increased swelling capacity in the starch granules; however, this aspect needs further investigation. High viscosity in $24 \mathrm{~h}$ sample is consistent with the small changes in starch structure and accessibility to hydrolysis (i.e. damaged starch) as reported in Table 1. 


\subsection{Effect of germination on gluten aggregation properties}

223 Germination caused a significant decrease in maximum torque (Fig. 2) and energy required for gluten aggregation (supplementary Table 1). Such changes in gluten aggregation properties observed during germination suggested a decrease in gluten strength and, thus flour quality. In general, it is assumed that the gluten quality of flour from sprouted wheat is too low for optimal baking performance due to proteolytic hydrolysis of gluten proteins.

The relation between peak maximum time $\left(R^{2}=0.96\right)$ and aggregation energy $\left(R^{2}=0.92\right)$ to sprouting time were more evident in refined flours than in wholegrain flours. Interestingly, the decrease in peak torque did not follow a linear trend. In particular, the highest value was measured in the sample that had been sprouted for $24 \mathrm{~h}$, suggesting that the behaviour of this sample needs further investigation.

Changes in gluten aggregation properties might suggest changes in protein profile. Indeed, a positive correlation has recently been found between gliadin content and maximum torque and between glutenins and unextractable polymeric protein (i.e. glutenins with the highest molecular weight) and GlutoPeak energy (Marti, Augst, Cox, \& Koehler, 2015). A marked decrease in the amount of insoluble residue protein (Simsek et al., 2014) and thus the formation of soluble peptides (Koehler et al., 2007) in sprouted wheat samples have already been shown to compromise the baking performance.of the flour In particular, during the first stages of germination (i.e. $48 \mathrm{~h}$ ) the degradation of glutenins was predominant, whereas longer germination times (i.e. $102 \mathrm{~h}$ ) were required to degrade gliadins (Koehler et al., 2007). In addition, low molecular weight subunits were less sensitive than high molecular weight subunits (Koehler et al., 2007), but unfortunately, these proteins are essential for strengthening the gluten network and for optimizing bread-making performance. On the other hand, germination under controlled conditions promoted a limited accumulation of proteases, so that gluten from sprouted wheat was still able to aggregate and form a network with good bread-making performance (Marti et al., 2017, 2018). 


\subsection{Principal component analysis (PCA) of data}

Explorative multivariate analysis via PCA was used to further explore the data and provide additional discriminatory power. Data from composition, enzymatic activities, starch pasting properties and gluten aggregation kinetics for wholegrain were autoscaled and submitted to PCA to obtain a biplot as reported in Figure 3a. The two principal components provided a good summary of the data, accounting for $83.43 \%$ of the overall variance $(\mathrm{PC} 1=58.27 \%$; $\mathrm{PC} 2=25.16 \%)$. The biplot visualisation allowed us to highlight differences among the samples.

Samples with different germination times were differentiated along PC1, with the $24 \mathrm{~h}$-sprouted sample having positive values, similar to CTRL, while samples with longer sprouting time resulted in negative PC1 values (Fig. 3a). Moreover, the biplot visualisation easily distinguishes the variables affecting most sample distributions, which are the ones more distant from the origin of the biplot. Alpha-amylase ( $\alpha$-am), protein (Prot), glucose (Glu), and maltose (Mal) content, together with pasting temperature in presence of $\mathrm{AgNO} 3$ (PT_Ag) were responsible for negative $\mathrm{PC} 1$ values in samples sprouted for 48, 60 and $72 \mathrm{~h}$ (Fig. 3a). Thus, these samples can be distinguished from the control and the $24 \mathrm{~h}$ - sprouted wholegrain flour based on these variables. Averaged data reported in Table 1, supplementary Table 1, and the related discussion agree with the behaviour highlighted in Fig. 3a.

PC2 clearly explains the difference between the control and 24h-sprouted sample, as well as all other samples (48, 60 and 72h). $\beta$-amylase activity ( $\beta$-am), peak temperature (PTemp) by RVA, together with Aggregation energy (AgEn), peak torque (MT) by GlutoPeak test were the predominant factors that distinguished the CTRL from the sprouted samples. Although most previous studies focused on the relation between sprouting and starch properties (Simsek et al., 2014), the results of the present study suggested that changes in protein aggregation properties during germination were also worth investigating. The biplot in Figure 3a also highlighted that the falling (FN) and stirring (SN) numbers were not able to differentiate between CTRL and 24hsprouted samples, confirming that both methods are not sensitive enough for evaluating low 
germination levels in wheat. In addition, the variables involved in distinguishing CTRL from 24hsprouted samples were: damaged starch content (DS, DS/TS), the peak maximum time (PMT) and the energy under the GlutoPeak curve, together with two indices obtained by RVA test in presence of AgNO3 (i.e. breakdown, BD, and peak viscosity, PV). Running the RVA test in the presence of the amylase inhibitor (i.e. AgNO3) is strategic in understanding the effect of sprouting on starch properties.

The same sample distribution was observed when the autoscaled refined flour data was submitted to PCA (Fig. 3b): the CTRL sample is positioned in the right-bottom quarter, the $24 \mathrm{~h}$-sprouted sample in the right- top quarter and the other samples are grouped over the top- and bottom- left quarters, with the $36 \mathrm{~h}$ and $48 \mathrm{~h}$ sprouted samples being close to each other, as well as the $60 \mathrm{~h}$ with $72 \mathrm{~h}$ samples. This groupof samples, as well as the corresponding wholegrain flours, was characterised by high average values of $\alpha$-amylase ( $\alpha$-am), maltose (Mal), glucose (Glu), aggregation time (PMT), pasting temperature in presence of $\mathrm{AgNO} 3$ (PT_Ag) as reported in Table 1 and supplementary Table 1 . In the right-top quarter, where the average of samples collected after $24 \mathrm{~h}$ of sprouting is located, there is a group of variables for which this sample results in statistically higher $(\mathrm{p}<0.05)$ average values compared to the other samples evaluated (Table 1 and supplementary Table 1).

Similarly, the right-bottom quarter shows the control sample positioned together with its characterising variables, such as $\beta$-amylase ( $\beta$-am), sucrose (Suc), proteins (Prot), Falling number (FN), GlutoPeak torque (MT), pasting temperature (PT), setback (SB), and final viscosity (FV). For all these variables the control consists of statistically higher values $(\mathrm{p}<0.05)$ than the sprouted samples, regardless of the germination time (Table 1 and supplementary Table 1). 


\subsection{MicroNIR data}

\subsubsection{Spectral features}

The averaged spectra of the dried kernels collected at each sampling point (CTRL, 24h, 36h, 48h, $60 \mathrm{~h}$ and $72 \mathrm{~h}$ ) with MicroNIR are shown in Supplementary Fig. 2a. Spectra were characterized by absorption bands at $980 \mathrm{~nm}(2 v 1+v 3), 1200 \mathrm{~nm}(v 1, v 2+v 3)$ and $1450 \mathrm{~nm}(\mathrm{v} 1+\mathrm{v} 3)$ ascribable to $\mathrm{OH}$ bounds present in water, starch and peptide groups; moreover, it is visible a shoulder at $1360 \mathrm{~nm}$ (C-H combination, .CH3) and one broad signal around 1500-1530 nm (2v of N-H) (Workman \& Weyer, 2008). Derivative transformation of the spectra (Fig. 3b) highlighted a further signal difference at $1225 \mathrm{~nm}$ linked to the second overtone (3v) of C-H (Workman \& Weyer, 2008). In a previous work on wheat sprouting evaluation, Juhász et al. (2005) associated the regions between 1154-1166 nm and 1456-1472 nm with moisture content and the signal detected between 1578 and $1582 \mathrm{~nm}$ with starch absorption.

The spectral profile of the CTRL sample's main absorption peaks differed greatly when compared to that of the sprouted samples. Analysing in detail the differences along the spectral range after derivative transformation (Supplementary Fig. 2b), a shift is registered from $1156 \mathrm{~nm}$ for the average signal recorded for the CTRL to $1150 \mathrm{~nm}$ for all the sprouted samples. This area is highly affected by moisture content but at $1200 \mathrm{~nm}$ a C-H second overtone influence was registered thus the shift could be linked to changes in the $\mathrm{CH}$ methylene portion of aliphatic groups (Workman \& Weyer, 2008). In the spectral region between $1480 \mathrm{~nm}$ and $1565 \mathrm{~nm}$ the difference in all the samples might be linked to the absorbance at $1450 \mathrm{~nm}$ present in the raw spectra due to the second overtone of $\mathrm{OH}$ mainly linked to changes in the starch fraction (Juhász et al., 2005) as the humidity differences are negligible $(10.1-13.2 \%)$. Similar patterns were observed for the spectra collected from wet kernels, except for the expected higher signals in correspondence of water absorption peaks (data not shown). 


\subsubsection{PCA of MicroNIR spectra}

Explorative data analysis by PCA was performed on the dataset constituted by spectra averaged by sampling point (CTRL, $24 \mathrm{~h}, 36 \mathrm{~h}, 48 \mathrm{~h}, 60 \mathrm{~h}$ and $72 \mathrm{~h}$ ) transformed with SNV and first derivative. The scores obtained for PC1 (67.28\% of explained variance) and PC2 (29.62\% of explained variance) highlighted differences among samples according to sprouting time (Fig. 4a). All the sprouted samples differed from the CTRL sample along PC1. The CTRL sample resulted in the highest PC1 scores, whereas with the advance of the sprouting time the scores registered lower values until stabilizing after $60 \mathrm{~h}$. Along PC2 there is a remarkable difference between the CTRL and $24 \mathrm{~h}$ sample, as well as with all other samples (48h, $60 \mathrm{~h}$ and $72 \mathrm{~h})$.

The variables most responsible for this distribution are those furthest from zero in the loading plot shown in Fig. 4b. The variables with the highest influence along PC1 are in correspondence of 1156, 1323 and $1391 \mathrm{~nm}$. The relevance of these variables in PC1 loadings confirmed the shift observed in Supplementary Fig. 2b ascribable to the first overtone of N-H (1500-1530 nm) and the combination band of C-H (1360 nm) (Workman \& Mayer, 2008). Sprouted samples characterised by negative PC1 scores are by contrast characterised by the features producing negative values for the PC1 loadings, i.e. at 1224 and $1434 \mathrm{~nm}$ related to raw spectra absorptions at 1200 and $1450 \mathrm{~nm}$ and linked to O-H vibrations (Workman \& Mayer, 2008). The loading analysis confirmed that changes in both starch and protein fractions are significant in identifying sprouting levels. The variables effecting PC2 the most - and thus contributing to the differentiation of sample $24 \mathrm{~h}$ from all the others - are 1180 and $1347 \mathrm{~nm}$ for the high positive pulling of CTRL and 1428, 1496 and $1546 \mathrm{~nm}$ for the negative pulling of the $24 \mathrm{~h}$ average sample, region mainly linked to changes in the absorbance at $1450 \mathrm{~nm}$ present in the raw spectra due to the second overtone of $\mathrm{OH}$ of the starch fraction (Workman \& Mayer, 2008).

The effect of germination was evaluated by PCA on spectra collected directly on wet kernels (Fig. 4c, d). A similar sample distribution was observed on the score plot obtained for the batchaveraged spectra corresponding to the sprouting time (Fig. 4c). In particular, the control sample (i.e. 
0), which in this case corresponds to kernels sampled directly after soaking, were well separated from the sprouted kernels along PC1. Germinated samples resulted in negative PC1 scores without remarkable differences regardless of time. Instead, the sprouting time difference is clearly distinguishable along PC2. Analysis of the loading plot (Fig. 4d) indicates that the separation between CTRL and the sprouted samples along PC1 is ascribable to different absorptions in the range 1500-1626 nm, related to starch absorption signals (Juhász et al., 2005). Likewise, the clustering of samples sprouted for $24 \mathrm{~h}$ and $36 \mathrm{~h}$, i.e. positioned in the top-left quadrant, opposite to samples germinated for longer time, i.e. samples located in the bottom-left quarter, were highly influenced by the absorption occurring in the range $1360-1440 \mathrm{~nm}$, probably related to $\mathrm{C}-\mathrm{H}$ combination bands present in the raw spectra at $1360 \mathrm{~nm}$ (Workman \& Mayer, 2008). Clearly the humidity of those samples influenced the recorded spectra, however the germination effect was clear also from those results and ascribable to both protein and starch fractions.

\subsection{Estimation of wheat germination time from the MicroNIR analysis on wet kernels}

PCA score values for data relating to the chemical composition and technological features of wholegrain flours and refined flours, together with the spectroscopic data on either wet or dry kernels were normalized between 0 and 1 and modelled against time to compare the resultant germination trajectories (Fig. 5). The PC1 scores of spectroscopic data collected directly on wet kernels showed the maximum velocity rate within the first 24 hours of germination followed by two distinctive curve trends: one from $24 \mathrm{~h}$ to $36 \mathrm{~h}$ and a second one after 48 hours until the end of the sampling (Fig. 5a). This behaviour differed from that observed for the spectroscopic results on dry kernels, which were comparable to the explorative analysis performed on chemical composition and technological features for wholegrain and refined flour. Indeed, the latter PC1 score trajectories revealed a consistent difference between $24 \mathrm{~h}$ samples and CTRL as well as for longer sprouting times. Moreover, the maximum velocity of the sprouting process peaked before $36 \mathrm{~h}$ and reached a plateau after $60 \mathrm{~h}$ only for dry kernels (Fig. 5a). 
Even if $\mathrm{PC} 1$ described the maximum variance of each dataset, it is not possible to assume that this variance is the most important factor in describing a process. In our case, evaluation of PC2 scores looked promising in describing the sprouting changes recorded using both conventional and spectroscopic approaches. Fig. 5b showed how 24h sample differed from CTRL and higher sprouted times. From $24 \mathrm{~h}$ on, all the PC2 trajectories registered a dramatic slow down up to $48 \mathrm{~h}$ followed by a plateau. The confluence of PC2 trajectories suggested that the most interesting changes due to chemical composition and technological features occurred in the first $48 \mathrm{~h}$ whereas longer germination times generated no further relevant changes. The results proved that the progress of controlled sprouting processes can be predicted by spectroscopic data collected directly on wet kernels, thus skipping both the drying and refinement steps, providing information very similar to that obtained by complex and time-consuming analyses on refined flour.

\section{Conclusions}

Changes in chemical composition, enzymatic activities, as well as starch and protein functionality were monitored during wheat sprouting under controlled conditions of temperature and relative humidity. Although the falling and stirring numbers are widely used to detect pre-harvest sprouting in wheat kernels, both of these methods seem to overestimate the extent of starch hydrolysis in sprouted wheat under controlled conditions. Running the test in the presence of an amylase inhibitor (i.e. AgNO3) would avoid misleading interpretations of the effect of sprouting on starch properties. In addition to starch, this study suggests that changes in protein aggregation properties during germination are worth investigating. Both starch and protein changes as affected by sprouting time might be recorded by using a portable Micro NIR device, directly on wet kernels, thus avoiding the drying and refinement steps, and yielding information similar to that obtained by conventional analyses on refined flour. The most interesting changes occurred in the first $48 \mathrm{~h}$, whereas longer germination times generated no further relevant changes. 
The results of this research will aid the food industry in formulating a product with consistent characteristics, by standardizing and monitoring the sprouting process. Monitoring the biochemical and functional changes during sprouting will lead to new opportunities for the manufacturing sector to offer a diversified selection of healthful and tasty products for consumers. Studies are underway to apply the method proposed here to monitor wheat germination directly in the field.

\section{Acknowledgements}

The authors wish to thank Viavi Solutions Inc. (Santa Rosa, CA) for the use of the MicroNIR OnSite 1700, and Molino Quaglia S.p.A. (Vighizzolo d'Este, Italy) for the use of the pilot plant. This work was supported by "Piano di sostegno alla Ricerca 2015/2017 -Linea 2 Azione A" project (University of Milan).

\section{References}

AACC International. Approved methods of analysis, 11th Ed. AACC International, St. Paul, MN, U.S.A.

Annor, G. A., Tyl, C., Marcone, M., Ragaee, S., Marti, A. 2017. Why do millets have slower starch and protein digestibility than other cereals? Trends in Food Science \& Technology 66, 73-83.

Bau, H., Villaume, C., Nicolas, J., Méjean, L. 1997. Effect of germination on chemical composition, biochemical constituents and antinutritional factors of soya bean (Glycine max) seeds. Journal of the Science of Food and Agriculture 73, 1-9.

Bellaio, S., Kappeler, S., Rosenfeld, E. Z., Jacobs, M. 2013. Partially germinated ingredients for naturally healthy and tasty products. Cereal Foods World 58, 55-59.

Burke, M., Small, D. M., Antolasic, F., Hughes, J. G., Spencer, M. J. S., Blanch, E. W., Jones, O. A. H. 2016. Infrared spectroscopy-based metabolomic analysis for the detection of preharvest sprouting in grain. Cereal Chemistry 93, 444-449.

Cozzolino, D. 2014. An overview of the use of infrared spectroscopy and chemometrics in authenticity and traceability of cereals. Food Research International 60, 262-265. 
Dhital, S., Warren, F. J., Butterworth, P. J., Ellis, P. R., Gidley, M. J. 2017. Mechanisms of starch digestion by $\alpha$-amylase - Structural basis for kinetic properties. Critical Reviews in Food Science and Nutrition 57, 875-892.

Elmaki, H. B., Babiker, E., El Tinay, A. H. 1999. Changes in chemical composition, grain malting, starch and tannin contents and protein digestibility during germination of sorghum cultivars. Food Chemistry 64, 331-336.

Erba, D., Angelino, D., Marti, A., Manini, F., Faoro, F., Morreale, F., Pellegrini, N., Casiraghi, M. C. 2018. Nutritional quality of sprouted and cooked chickpeas and green peas. International Journal of Food Sciences and Nutrition. https://doi.org/10.1080/09637486.2018.1478393.

Faltermaier, A., Zarnkow, M., Becker, T., Gastl, M., Arendt, E. K. 2015. Common wheat (Triticum aestivum L.): evaluating microstructural changes during the malting process by using confocal laser scanning microscopy and scanning electron microscopy. European Food Research and Technology 241, 239-252.

Fox, G., Manley, M. 2014. Applications of single kernel conventional and hyperspectral imaging near infrared spectroscopy in cereals. Journal of the Science of Food and Agriculture 94, 174179.

Grassi, S., Casiraghi, E., Alamprese, C. 2018. Handheld NIR device: A non-targeted approach to assess authenticity of fish fillets and patties. Food Chemistry 243, 382-388.

Hübner, F., Arendt, E. K. 2013. Germination of cereal grains as a way to improve the nutritional value: a review. Critical Reviews in Food Science and Nutrition 53, 853-861.

Juhász, R., Gergely, S., Gelencsér, T., Salgó, A. 2005. Relationship between NIR spectra and RVA parameters during wheat germination. Cereal Chemistry 82, 488-493.

Koehler, P., Hartmann, G., Wieser, H., Rychlik, M. 2007. Changes of folates, dietary fiber, and proteins in wheat as affected by germination. Journal of Agricultural and Food Chemistry 55, $4678-4683$. 
Kruger, J. E. (1994). Enzymes of sprouted wheat and their possible technological significance. In W. Bushuk \& V. F. Rasper (Eds.), Wheat: production, properties and quality (pp. 143-153). Boston: Springer Science \& Business Media.

Lorenz, K., Collins, F., Kulp, K. 1981. Sprouting of cereal grains - Effects on starch characteristics. Starch-Stärke 33, 183-187.

Lorenz, K.,Valvano, R. 1981. Functional characteristics of sprout-damaged soft white wheat flours. Journal of Food Science 46, 1018-1020.

MacArthur, L. A., D’Appolonia, B. L., Banasik, O. J. 2009. The Falling Number test - What is it and how does it work? Farm Research 38, 15-22.

Marengo, M., Carpen, A., Bonomi, F., Casiraghi, M. C., Meroni, E., Quaglia, L., Iametti, S., Pagani, M.A., Marti, A. 2017. Macromolecular and micronutrient profiles of sprouted chickpeas to be used for integrating cereal-based food. Cereal Chemistry $94,82-88$.

Marti, A., Augst, E., Cox, S., Koehler, P. 2015. Correlations between gluten aggregation properties defined by the GlutoPeak test and content of quality-related protein fractions of winter wheat flour. Journal of Cereal Science 66, 89-95.

Marti, A., Cardone, G., Nicolodi, A., Quaglia, L., Pagani, M. A. 2017. Sprouted wheat as an alternative to conventional flour improvers in bread-making. LWT - Food Science and Technology, 80, 230-236.

Marti, A., Cardone, G., Pagani, M. A., Casiraghi, M. C. 2018. Flour from sprouted wheat as a new ingredient in bread-making. LWT - Food Science and Technology 89, 237-243.

Marti, A., Ulrici, A., Foca, G., Quaglia, L., Pagani, M. A. 2015. Characterization of common wheat flours (Triticum aestivum L.) through multivariate analysis of conventional rheological parameters and gluten peak test indices. LWT - Food Science and Technology 64, 95-103. 
467 Olaerts, H., Roye, C., Derde, L. J., Sinnaeve, G., Meza, W. R., Bodson, B., \& Courtin, C. M. 2016. 468 Impact of preharvest sprouting of wheat (Triticum aestivum) in the field on starch, protein, and 469 arabinoxylan properties. Journal of Agricultural and Food Chemistry 64, 8324-8332.

470 Simsek, S., Ohm, J. B., Lu, H., Rugg, M., Berzonsky, W., Alamri, M., Mergoum, M. 2014. Effect 471 of pre-harvest sprouting on physicochemical properties of starch in wheat. Foods 3, 194-207. 472 Singh, C. B., Jayas, D. S., Paliwal, J., White, N. D. G. 2009. Detection of sprouted and midge473 damaged wheat kernels using near-infrared hyperspectral imaging. Cereal Chemistry 86, 256474260.

475 Workman, J., Weyer, L. 2008. Practical guide to interpretive near-infrared spectroscopy (1st ed.). $476 \quad$ Boca Raton: CRC Press Inc.

477 Yang, T. K., Basu, B., Ooraikul, F. 2001. Studies on germination conditions and antioxidant 478 contents of wheat grain. International Journal of Food Sciences and Nutrition 52, 319-330. 479 Ziegler, P. (1995). Carbohydrate degradation during seed development. In J. Kigel \& G. Galili 480 (Eds.), Seed Development and Germination (pp. 447-474). New York: Marcel Dekker Inc. 


\section{Figure captions}

Figure 1. Effect of germination time on starch pasting properties of wholegrain $(a, b)$ and refined flour (c, d), using water (a, c) or $\mathrm{AgNO}_{3}(\mathrm{~b}, \mathrm{~d})$ as solvent.

Figure 2. Effect of germination time on aggregation properties of wholegrain (a) and refined flour (b).

Figure 3. Principal Component Analysis on data from composition, enzymatic activities, starch pasting properties and gluten aggregation kinetics: (a) biplot obtained for whole grain flour data; (b) biplot obtained for refined flour data.

Figure 4. Principal Component Analysis on MicroNIR spectra collected on dried $(a, b)$ and wet (c, d) sprouted grains at each sampling point (CTRL, 24h, 36h, 48h, 62h and 72h): (a, c) scores plot of PC1 and PC2; (b, d) loadings plot of PC1 and PC2.

Figure 5. Normalised scores vs sprouting time obtained from Principal Component Analysis on MicroNIR data on wet kernels ( $\mathbf{\square})$, MicroNIR data on dry kernels ( $\bullet$ ), data from composition, enzymatic activities, starch pasting properties and gluten aggregation kinetics of whole grain $(\bullet)$ and refined flour ( $\mathbf{\Delta}$ ): (a) PC1 scores vs sprouting time; (b) PC2 scores vs sprouting time.

Supplementary Figure 1. Details of the shaker probe of the MicroNIR OnSite (VIAVI, Santa Rosa, CA) while spectra acquisition.

Supplementary Figure 2. Averaged MicroNIR spectra collected on dried sprouted grains at each sampling point (CTRL, 24h, 36h, 48h, 62h and 72h): (a) raw spectra; (b) spectra after smoothing and first derivative transformation. 
Table 1. Effect of germination time on chemical composition and enzymatic activities of wholegrain and refined flour.

\begin{tabular}{|c|c|c|c|c|c|c|c|c|}
\hline & & & CTRL & $24 \mathrm{~h}$ & $38 \mathrm{~h}$ & $48 \mathrm{~h}$ & $60 \mathrm{~h}$ & $72 \mathrm{~h}$ \\
\hline \multirow{11}{*}{$\begin{array}{l}\text { Wholegrain } \\
\text { flour }\end{array}$} & \multirow{7}{*}{$\begin{array}{l}\text { Chemical } \\
\text { composition }\end{array}$} & Total starch $(\mathrm{g} / 100 \mathrm{~g} \mathrm{db})$ & $66.3 \pm 1.1^{\mathrm{b}}$ & $65.7 \pm 0.6^{\mathrm{ab}}$ & $65.5 \pm 1.2^{\mathrm{ab}}$ & $66.3 \pm 0.1^{\mathrm{ab}}$ & $64.8 \pm 0.8^{\mathrm{ab}}$ & $62.9 \pm 2.7^{\mathrm{a}}$ \\
\hline & & Damage starch $(\mathrm{g} / 100 \mathrm{~g} \mathrm{db})$ & $2.69 \pm 0.1^{\mathrm{a}}$ & $3.51 \pm 0.1^{\mathrm{c}}$ & $2.73 \pm 0.1^{\mathrm{a}}$ & $2.96 \pm 0.1^{\mathrm{b}}$ & $2.84 \pm 0.1^{\mathrm{ab}}$ & $2.84 \pm 0.1^{\mathrm{ab}}$ \\
\hline & & Damage starch/Total Starch (g/100g db) & $4.06 \pm 0.1^{\mathrm{a}}$ & $5.34 \pm 0.1^{\mathrm{d}}$ & $4.16 \pm 0.1^{\mathrm{b}}$ & $4.46 \pm 0.2^{\mathrm{bc}}$ & $4.38 \pm 0.1^{\mathrm{bc}}$ & $4.52 \pm 0.1^{\mathrm{c}}$ \\
\hline & & Maltose $(\mathrm{g} / 100 \mathrm{~g} \mathrm{db})$ & $0.14 \pm 0.06^{\mathrm{a}}$ & $0.23 \pm 0.09^{\mathrm{a}}$ & $0.44 \pm 0.12^{\mathrm{ab}}$ & $0.86 \pm 0.11^{\mathrm{b}}$ & $0.82 \pm 0.13^{\mathrm{b}}$ & $0.86 \pm 0.11^{\mathrm{b}}$ \\
\hline & & Sucrose $(\mathrm{g} / 100 \mathrm{~g} \mathrm{db})$ & $1.22 \pm 0.01^{\mathrm{a}}$ & $1.23 \pm 0.02^{\mathrm{a}}$ & $1.32 \pm 0.03^{\mathrm{a}}$ & $1.18 \pm 0.01^{\mathrm{a}}$ & $1.24 \pm 0.10^{\mathrm{a}}$ & $1.23 \pm 0.07^{\mathrm{a}}$ \\
\hline & & D-glucose $(g / 100 \mathrm{~g} \mathrm{db})$ & $0.07 \pm 0.01^{\mathrm{a}}$ & $0.08 \pm 0.01^{\mathrm{a}}$ & $0.09 \pm 0.01^{\mathrm{ab}}$ & $0.16 \pm 0.01^{\mathrm{c}}$ & $0.12 \pm 0.01^{\mathrm{bc}}$ & $0.15 \pm 0.01^{\mathrm{c}}$ \\
\hline & & Proteins $(g / 100 g \mathrm{db})$ & $12.9 \pm 0^{\mathrm{a}}$ & $13.1 \pm 0^{\mathrm{ab}}$ & $13.4 \pm 0.1^{\mathrm{bcd}}$ & $13.2 \pm 0.3^{\mathrm{abc}}$ & $13.7 \pm 0.2^{\mathrm{d}}$ & $13.6 \pm 0.1^{\mathrm{cd}}$ \\
\hline & \multirow{4}{*}{$\begin{array}{l}\text { Enzymatic } \\
\text { activities }\end{array}$} & $\alpha$-amylase (UC/g db) & $0.1 \pm 0^{\mathrm{a}}$ & $4.3 \pm 0.5^{\mathrm{b}}$ & $5.2 \pm 0.5^{\mathrm{b}}$ & $7.9 \pm 1.4^{\mathrm{bc}}$ & $8.5 \pm 1.6^{\mathrm{c}}$ & $9.6 \pm 1.2^{\mathrm{c}}$ \\
\hline & & $\beta$-amylase (UB/g db) & $34.2 \pm 1.8^{\mathrm{b}}$ & $25.1 \pm 0.5^{\mathrm{a}}$ & $30.1 \pm 1.5^{\mathrm{b}}$ & $30.2 \pm 0.7^{b}$ & $31.0 \pm 0.2^{\mathrm{b}}$ & $32.1 \pm 1.4^{\mathrm{b}}$ \\
\hline & & Falling number (s) & $417 \pm 0^{\mathrm{e}}$ & $314 \pm 8^{\mathrm{d}}$ & $210 \pm 1^{\mathrm{c}}$ & $155 \pm 1^{\mathrm{b}}$ & $141 \pm 1^{\mathrm{b}}$ & $98 \pm 1^{\mathrm{a}}$ \\
\hline & & Stirring number $(\mathrm{cP})$ & $124 \pm 1.1^{\mathrm{e}}$ & $126 \pm 1.4^{\mathrm{e}}$ & $68 \pm 1.2^{\mathrm{d}}$ & $35 \pm 0.4^{\mathrm{c}}$ & $23 \pm 0.7^{b}$ & $14 \pm 0.2^{\mathrm{a}}$ \\
\hline \multirow{11}{*}{$\begin{array}{l}\text { Refined } \\
\text { wheat flour }\end{array}$} & \multirow{7}{*}{$\begin{array}{l}\text { Chemical } \\
\text { composition }\end{array}$} & Total starch $(\mathrm{g} / 100 \mathrm{~g} \mathrm{db})$ & $76.4 \pm 0.9^{\mathrm{ab}}$ & $78.1 \pm 1.8^{\mathrm{b}}$ & $74.1 \pm 1.0^{\mathrm{a}}$ & $76.8 \pm 1.0^{\mathrm{ab}}$ & $76.4 \pm 1.7^{\mathrm{ab}}$ & $77.3 \pm 1.9^{\mathrm{ab}}$ \\
\hline & & Damage starch $(g / 100 g$ db) & $4.82 \pm 0.1^{\mathrm{a}}$ & $5.75 \pm 0.3^{\mathrm{b}}$ & $4.57 \pm 0.1^{\mathrm{a}}$ & $4.65 \pm 0.1^{\mathrm{a}}$ & $4.73 \pm 0.2^{\mathrm{a}}$ & $4.61 \pm 0.1^{\mathrm{a}}$ \\
\hline & & Damage starch/Total Starch (g/100g db) & $6.31 \pm 0.2^{\mathrm{a}}$ & $7.36 \pm 0.3^{b}$ & $6.16 \pm 0.2^{\mathrm{a}}$ & $5.85 \pm 0.4^{\mathrm{a}}$ & $6.19 \pm 0.2^{\mathrm{a}}$ & $5.96 \pm 0.2^{\mathrm{a}}$ \\
\hline & & Maltose $(\mathrm{g} / 100 \mathrm{~g} \mathrm{db})$ & $0.84 \pm 0.21^{\mathrm{a}}$ & $1.32 \pm 0.23^{\mathrm{ab}}$ & $1.79 \pm 0.18^{\mathrm{bc}}$ & $1.89 \pm 0.11^{\mathrm{bc}}$ & $2.39 \pm 0.21^{\mathrm{c}}$ & $2.28 \pm 0.25^{\mathrm{c}}$ \\
\hline & & Sucrose $(g / 100 g \mathrm{db})$ & $0.82 \pm 0.10^{\mathrm{b}}$ & $0.57 \pm 0.03^{\mathrm{ab}}$ & $0.73 \pm 0.07^{\mathrm{ab}}$ & $0.54 \pm 0.05^{\mathrm{a}}$ & $0.51 \pm 0.10^{\mathrm{a}}$ & $0.58 \pm 0.07^{\mathrm{a}}$ \\
\hline & & D-glucose $(g / 100 \mathrm{~g} \mathrm{db})$ & $0.02 \pm 0.01^{\mathrm{a}}$ & $0.04 \pm 0.01^{\mathrm{ab}}$ & $0.05 \pm 0.01^{\mathrm{ab}}$ & $0.03 \pm 0.02^{\mathrm{ab}}$ & $0.12 \pm 0.04^{\mathrm{c}}$ & $0.08 \pm 0.01^{\mathrm{bc}}$ \\
\hline & & Proteins $(\mathrm{g} / 100 \mathrm{~g} \mathrm{db})$ & $13.9 \pm 0.2^{\mathrm{c}}$ & $13.1 \pm 0.2^{\mathrm{b}}$ & $12.6 \pm 0.1^{\mathrm{a}}$ & $12.8 \pm 0.2^{\mathrm{ab}}$ & $12.9 \pm 0.1^{\mathrm{b}}$ & $12.6 \pm 0.1^{\mathrm{a}}$ \\
\hline & \multirow{4}{*}{$\begin{array}{l}\text { Enzymatic } \\
\text { activities }\end{array}$} & $\alpha$-amylase (UC/g db) & $0.1 \pm 0^{\mathrm{a}}$ & $6.8 \pm 0.5^{\text {cd }}$ & $6.3 \pm 0.6^{\mathrm{bc}}$ & $5.0 \pm 0.5^{\mathrm{b}}$ & $8.4 \pm 0.5^{\mathrm{d}}$ & $7.4 \pm 1.2^{\text {cd }}$ \\
\hline & & $\beta$-amylase (UB/g db) & $37.2 \pm 0.7^{\mathrm{c}}$ & $28.5 \pm 1.2^{\mathrm{a}}$ & $30.0 \pm 0.5^{\mathrm{ab}}$ & $31.4 \pm 0.8^{\mathrm{ab}}$ & $31.2 \pm 0.4^{\mathrm{ab}}$ & $32.1 \pm 0.9^{b}$ \\
\hline & & Falling number (s) & $334 \pm 5^{\mathrm{e}}$ & $226 \pm 11^{d}$ & $198 \pm 1^{\text {cd }}$ & $168 \pm 16^{\mathrm{bc}}$ & $135 \pm 8^{\mathrm{ab}}$ & $124 \pm 2^{\mathrm{a}}$ \\
\hline & & Stirring number $(\mathrm{cP})$ & $121 \pm 1.6^{\mathrm{f}}$ & $110 \pm 3.0^{\mathrm{e}}$ & $61 \pm 0.4^{\mathrm{d}}$ & $43 \pm 0.4^{\mathrm{c}}$ & $24 \pm 0.1^{\mathrm{b}}$ & $18 \pm 0.1^{\mathrm{a}}$ \\
\hline
\end{tabular}

Different letters in the same row indicate significant differences (Tukey HD test; $\mathrm{p}<0.05$ ). 
Supplementary Table 1. Effect of germination time on starch pasting and gluten aggregation properties of wholegrain and refined flour.

\begin{tabular}{|c|c|c|c|c|c|c|c|c|}
\hline & & & CTRL & $24 \mathrm{~h}$ & $38 \mathrm{~h}$ & $48 \mathrm{~h}$ & $60 \mathrm{~h}$ & $72 \mathrm{~h}$ \\
\hline \multirow{16}{*}{$\begin{array}{l}\text { Wholegrain } \\
\text { flour }\end{array}$} & \multirow{6}{*}{$\begin{array}{l}\text { Pasting } \\
\text { properties } \\
\text { (water) }\end{array}$} & Pasting temperature $\left({ }^{\circ} \mathrm{C}\right)$ & $84.9 \pm 0.2^{\mathrm{d}}$ & $83.8 \pm 0.2^{\mathrm{d}}$ & $82.1 \pm 0.4^{\mathrm{c}}$ & $77.1 \pm 0.1^{\mathrm{b}}$ & $72.7 \pm 0.5^{\mathrm{a}}$ & $71.6 \pm 0.1^{\mathrm{a}}$ \\
\hline & & Peak temperature $\left({ }^{\circ} \mathrm{C}\right)$ & $95.0 \pm 0.0^{\mathrm{e}}$ & $94.8 \pm 0.1^{\mathrm{e}}$ & $92.9 \pm 0.3^{\mathrm{d}}$ & $86.1 \pm 0.3^{\mathrm{c}}$ & $80.9 \pm 0.4^{\mathrm{b}}$ & $78.1 \pm 0.4^{\mathrm{a}}$ \\
\hline & & Peak viscosity (cP) & $1890 \pm 29.7^{\mathrm{d}}$ & $1819.5 \pm 55.9^{\mathrm{d}}$ & $671 \pm 39.6^{\mathrm{c}}$ & $339.5 \pm 9.2^{\mathrm{b}}$ & $240.5 \pm 0.7^{\mathrm{ab}}$ & $196.5 \pm 6.4^{\mathrm{a}}$ \\
\hline & & Breakdown $(\mathrm{cP})$ & $695 \pm 24^{\mathrm{d}}$ & $938 \pm 33.2^{\mathrm{e}}$ & $498 \pm 28.3^{c}$ & $268 \pm 2.1^{\mathrm{b}}$ & $188 \pm 1.4^{\mathrm{ab}}$ & $154 \pm 4.9^{\mathrm{a}}$ \\
\hline & & Final viscosity $(\mathrm{cP})$ & $2578 \pm 9.9^{\mathrm{d}}$ & $1944.5 \pm 65.8^{\mathrm{c}}$ & $369 \pm 26.9^{b}$ & $119.5 \pm 10.6^{\mathrm{a}}$ & $79 \pm 1.4^{\mathrm{a}}$ & $63.5 \pm 2.1^{\mathrm{a}}$ \\
\hline & & Setback (cP) & $1383 \pm 4.2^{\mathrm{d}}$ & $1063 \pm 43.1^{\mathrm{c}}$ & $196 \pm 15.6^{b}$ & $48 \pm 3.5^{\mathrm{a}}$ & $27 \pm 0.7^{\mathrm{a}}$ & $21 \pm 0.7^{\mathrm{a}}$ \\
\hline & \multirow{6}{*}{$\begin{array}{c}\text { Pasting } \\
\text { properties } \\
\left(\mathrm{AgNO}_{3}\right)\end{array}$} & Pasting temperature $\left({ }^{\circ} \mathrm{C}\right)$ & $84.9 \pm 0.3^{\mathrm{a}}$ & $84.9 \pm 0.2^{\mathrm{a}}$ & $86.2 \pm 0.4^{\mathrm{b}}$ & $85.6 \pm 0.0^{\mathrm{ab}}$ & $85.7 \pm 0.2^{\mathrm{ab}}$ & $85.9 \pm 0.0^{\mathrm{b}}$ \\
\hline & & Peak temperature $\left({ }^{\circ} \mathrm{C}\right)$ & $94.9 \pm 0.03^{\mathrm{a}}$ & $94.8 \pm 0.3^{\mathrm{a}}$ & $94.9 \pm 0.04^{\mathrm{a}}$ & $94.9 \pm 0.1^{\mathrm{a}}$ & $94.8 \pm 0.04^{\mathrm{a}}$ & $94.9 \pm 0.04^{\mathrm{a}}$ \\
\hline & & Peak viscosity (cP) & $2082 \pm 4.2^{\mathrm{b}}$ & $2471.5 \pm 17.7^{\mathrm{c}}$ & $2161.5 \pm 27.6^{\mathrm{b}}$ & $2115.5 \pm 46^{\mathrm{b}}$ & $1979 \pm 5.7^{\mathrm{a}}$ & $1977.5 \pm 2.1^{\mathrm{a}}$ \\
\hline & & Breakdown $(\mathrm{cP})$ & $712 \pm 7.8^{\mathrm{a}}$ & $1014 \pm 18.4^{\mathrm{c}}$ & $841 \pm 21.9^{b}$ & $810 \pm 26.2^{\mathrm{ab}}$ & $699 \pm 61.5^{\mathrm{a}}$ & $766 \pm 10.6^{\mathrm{ab}}$ \\
\hline & & Final viscosity (cP) & $2904.5 \pm 10.7^{\mathrm{bc}}$ & $3051.5 \pm 26.2^{\mathrm{c}}$ & $2784 \pm 24^{\mathrm{ab}}$ & $2753 \pm 55.2^{\mathrm{ab}}$ & $2694 \pm 138.6^{\mathrm{ab}}$ & $2556.5 \pm 9.2^{\mathrm{a}}$ \\
\hline & & Setback (cP) & $1534 \pm 2.8^{\mathrm{b}}$ & $1594 \pm 26.9^{b}$ & $1463 \pm 18.4^{\mathrm{ab}}$ & $1447 \pm 35.4^{\mathrm{ab}}$ & $1414 \pm 82.7^{\mathrm{ab}}$ & $1345 \pm 3.5^{\mathrm{a}}$ \\
\hline & \multirow{4}{*}{$\begin{array}{c}\text { Gluten } \\
\text { aggregation } \\
\text { properties }\end{array}$} & Peak maximum time (s) & $122.5 \pm 6.4^{\mathrm{a}}$ & $152.5 \pm 0.7^{\mathrm{c}}$ & $133 \pm 7.1^{\mathrm{ab}}$ & $122.5 \pm 3.5^{\mathrm{a}}$ & $128 \pm 1.4^{\mathrm{ab}}$ & $140.5 \pm 2.1^{\mathrm{bc}}$ \\
\hline & & Maximum torque (GPU) & $50.8 \pm 0.3^{\mathrm{b}}$ & $43.7 \pm 0.4^{\mathrm{a}}$ & $45.95 \pm 1.3^{\mathrm{a}}$ & $42.95 \pm 1.3^{\mathrm{a}}$ & $45.15 \pm 1.6^{\mathrm{a}}$ & $42.95 \pm 1.1^{\mathrm{a}}$ \\
\hline & & Aggregation energy (GPE) & $1142 \pm 21.2^{\mathrm{c}}$ & $1047 \pm 3.5^{\mathrm{ab}}$ & $1071 \pm 17.7^{b}$ & $1015 \pm 12.7^{\mathrm{ab}}$ & $1051 \pm 13.4^{\mathrm{ab}}$ & $1011 \pm 13.4^{\mathrm{a}}$ \\
\hline & & Total energy (GPE) & $2071 \pm 2.8^{\mathrm{ab}}$ & $2507 \pm 4.2^{\mathrm{c}}$ & $2207 \pm 10.6^{\mathrm{b}}$ & $2027 \pm 11.3^{\mathrm{a}}$ & $2104 \pm 88.4^{\mathrm{ab}}$ & $2102 \pm 29.7^{\mathrm{ab}}$ \\
\hline \multirow{12}{*}{$\begin{array}{l}\text { Refined } \\
\text { wheat flour }\end{array}$} & \multirow{6}{*}{$\begin{array}{l}\text { Pasting } \\
\text { properties } \\
\text { (water) }\end{array}$} & Pasting temperature $\left({ }^{\circ} \mathrm{C}\right)$ & $84.9 \pm 0.2^{\mathrm{d}}$ & $81.2 \pm 0.3^{\mathrm{c}}$ & $83.2 \pm 1.1^{\mathrm{cd}}$ & $76.5 \pm 0.3^{\mathrm{b}}$ & $73.7 \pm 0.04^{\mathrm{a}}$ & $71.8 \pm 0.2^{\mathrm{a}}$ \\
\hline & & Peak temperature $\left({ }^{\circ} \mathrm{C}\right)$ & $95.0 \pm 0.1^{\mathrm{e}}$ & $95.1 \pm 0.0^{\mathrm{e}}$ & $92.5 \pm 0.3^{\mathrm{d}}$ & $87.9 \pm 0.1^{\mathrm{c}}$ & $81.7 \pm 0.3^{b}$ & $79.2 \pm 0.3^{\mathrm{a}}$ \\
\hline & & Peak viscosity $(\mathrm{cP})$ & $1837 \pm 26.2^{\mathrm{e}}$ & $1420 \pm 32.5^{\mathrm{d}}$ & $647 \pm 14.1^{\mathrm{c}}$ & $407 \pm 4.2^{\mathrm{b}}$ & $272 \pm 1.4^{\mathrm{a}}$ & $242 \pm 0.0^{\mathrm{a}}$ \\
\hline & & Breakdown (cP) & $744 \pm 5.7^{\mathrm{d}}$ & $923 \pm 14.1^{\mathrm{e}}$ & $504 \pm 7.1^{\mathrm{c}}$ & $327 \pm 4.2^{\mathrm{b}}$ & $223.5 \pm 0.7^{\mathrm{a}}$ & $200.5 \pm 0.7^{\mathrm{a}}$ \\
\hline & & Final viscosity (cP) & $2354.5 \pm 27.6^{\mathrm{d}}$ & $1180.5 \pm 40.3^{\mathrm{c}}$ & $314.5 \pm 17.7^{\mathrm{b}}$ & $143 \pm 0.0^{\mathrm{a}}$ & $72 \pm 0.0^{\mathrm{a}}$ & $60 \pm 1.4^{\mathrm{a}}$ \\
\hline & & Setback (cP) & $1261 \pm 7.1^{\mathrm{e}}$ & $683.5 \pm 21.9^{\mathrm{d}}$ & $171.5 \pm 10.6^{\mathrm{c}}$ & $63 \pm 0.0^{\mathrm{b}}$ & $23.5 \pm 0.7^{\mathrm{ab}}$ & $18.5 \pm 2.1^{\mathrm{a}}$ \\
\hline & \multirow{6}{*}{$\begin{array}{c}\text { Pasting } \\
\text { properties } \\
\left(\mathrm{AgNO}_{3}\right)\end{array}$} & Pasting temperature $\left({ }^{\circ} \mathrm{C}\right)$ & $84.7 \pm 0.1^{\mathrm{a}}$ & $84.2 \pm 0.2^{\mathrm{a}}$ & $85.3 \pm 0.3^{\mathrm{a}}$ & $84.9 \pm 0.2^{\mathrm{a}}$ & $85.1 \pm 0.5^{\mathrm{a}}$ & $85.3 \pm 0.2^{\mathrm{a}}$ \\
\hline & & Peak temperature $\left({ }^{\circ} \mathrm{C}\right)$ & $95.0 \pm 0.03^{\mathrm{a}}$ & $95.0 \pm 0.03^{\mathrm{a}}$ & $95.0 \pm 0.04^{\mathrm{a}}$ & $95.0 \pm 0.0^{\mathrm{a}}$ & $95.0 \pm 0.1^{\mathrm{a}}$ & $95.0 \pm 0.0^{\mathrm{a}}$ \\
\hline & & Peak viscosity (cP) & $2116 \pm 11.3^{\mathrm{c}}$ & $2572 \pm 7.1^{\mathrm{e}}$ & $2192 \pm 10.6^{\mathrm{d}}$ & $2059 \pm 6.4^{b}$ & $2010 \pm 23.3^{\mathrm{ab}}$ & $1959 \pm 11.3^{\mathrm{a}}$ \\
\hline & & Breakdown (cP) & $807 \pm 17.7^{\mathrm{ab}}$ & $1129 \pm 4.9^{\mathrm{d}}$ & $922 \pm 10.6^{\mathrm{c}}$ & $828 \pm 8.5^{\mathrm{b}}$ & $803 \pm 27.6^{\mathrm{ab}}$ & $759 \pm 4.2^{\mathrm{a}}$ \\
\hline & & Final viscosity $(\mathrm{cP})$ & $2753 \pm 10.6^{\mathrm{d}}$ & $3030 \pm 21.2^{\mathrm{e}}$ & $2679 \pm 1.4^{\mathrm{c}}$ & $2586 \pm 21.9^{\mathrm{b}}$ & $2540 \pm 0.7^{\mathrm{ab}}$ & $2509 \pm 2.1^{\mathrm{a}}$ \\
\hline & & Setback (cP) & $1444 \pm 17^{\mathrm{c}}$ & $1587.5 \pm 19.1^{\mathrm{d}}$ & $1410 \pm 1.4^{\mathrm{bc}}$ & $1355 \pm 24^{\mathrm{ab}}$ & $1333 \pm 3.5^{\mathrm{a}}$ & $1309 \pm 9.2^{\mathrm{a}}$ \\
\hline
\end{tabular}




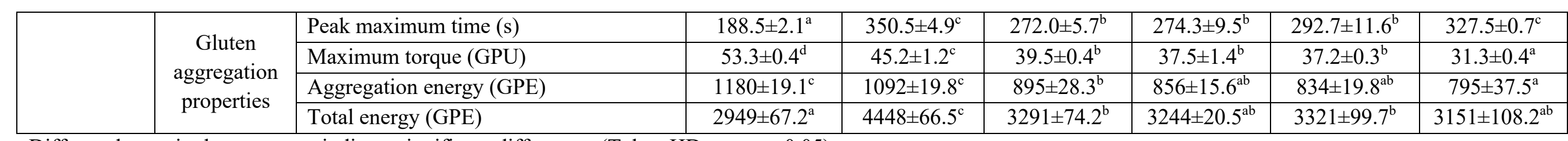

Different letters in the same row indicate significant differences (Tukey HD test; $p<0.05$ ) 

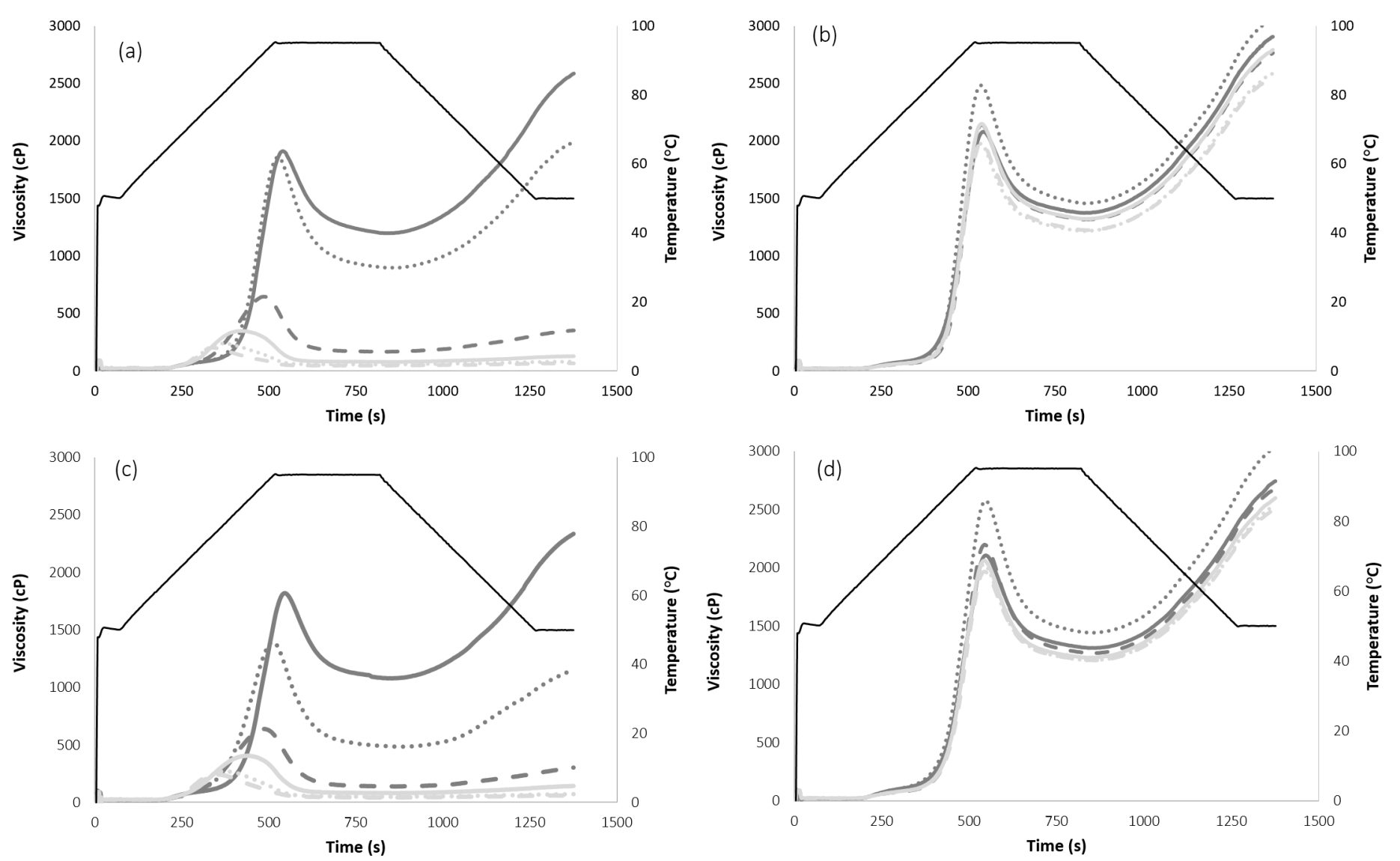

- CTRL $\cdots 24 \mathrm{~h}--38 \mathrm{~h}-48 \mathrm{~h} \cdots 60 \mathrm{~h}--72 \mathrm{~h}$ - Temperature

Figure 1. Effect of germination time on starch pasting properties of wholegrain $(a, b)$ and refined flour $(c, d)$, using water $(a, c)$ or $\mathrm{AgNO}_{3}(\mathrm{~b}, \mathrm{~d})$ as solvent. 


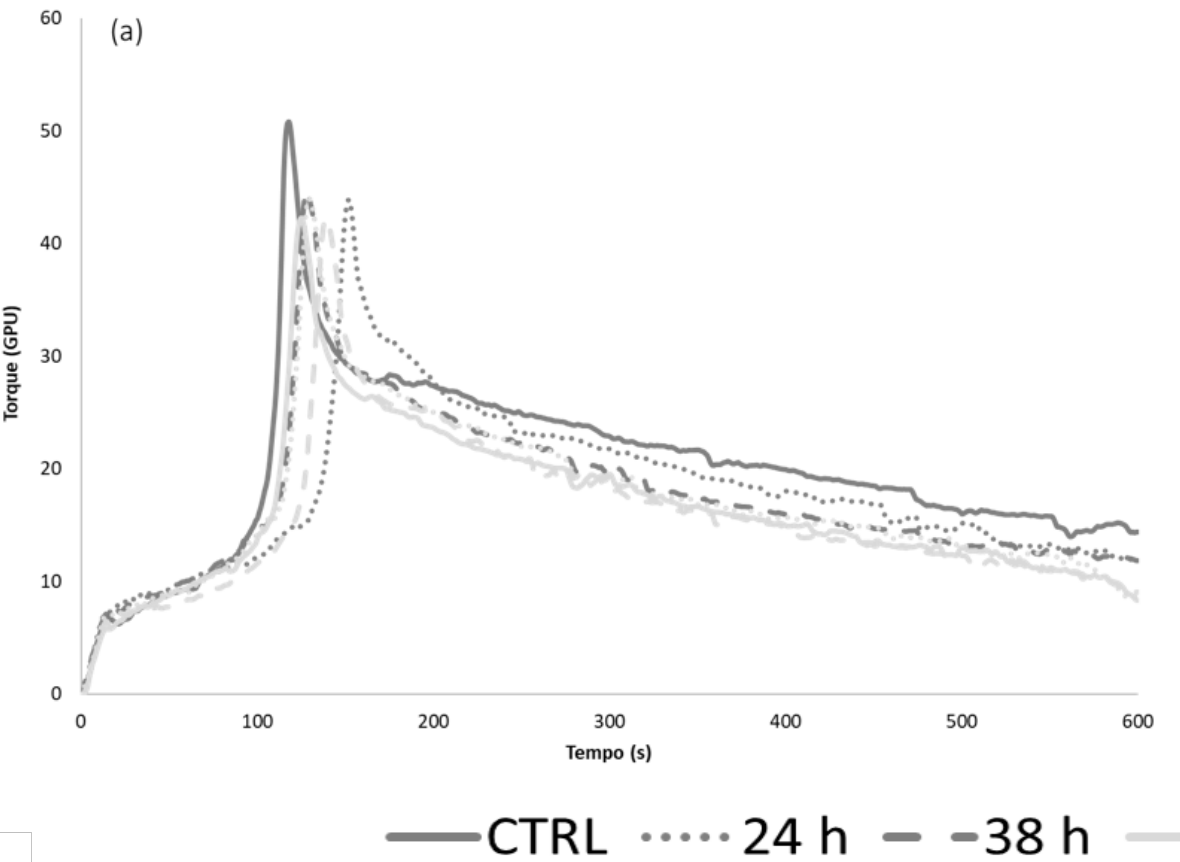

60 (b)

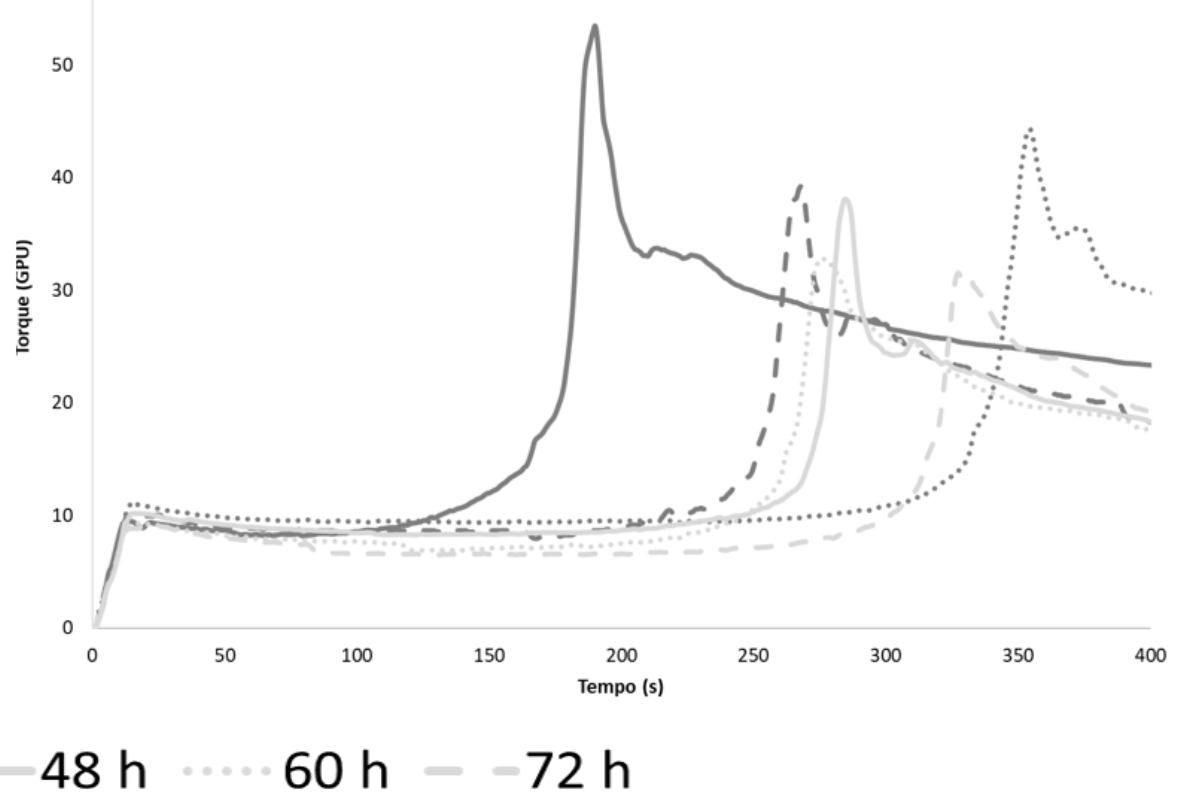

Figure 2. Effect of germination time on aggregation properties of wholegrain (a) and refined flour (b). 

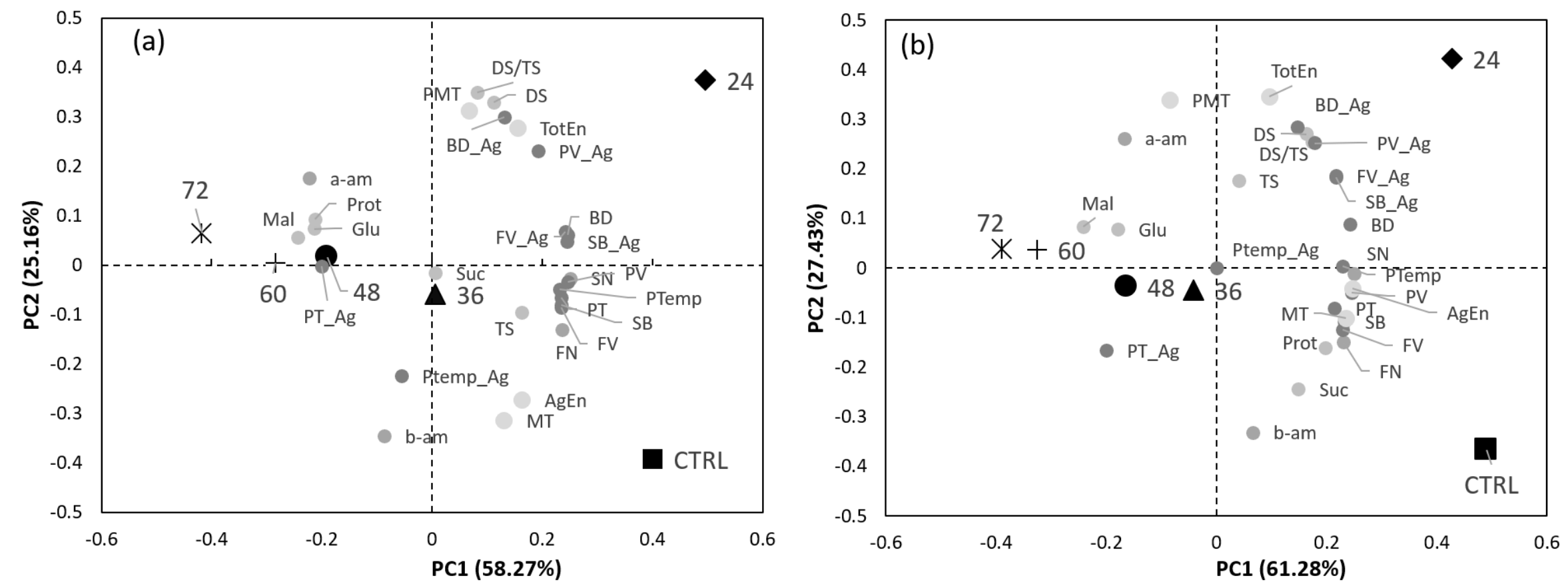

Figure 3. Principal Component Analysis on data from composition, enzymatic activities, starch pasting properties and gluten aggregation kinetics:

(a) biplot obtained for whole grain flour data; (b) biplot obtained for refined flour data. 

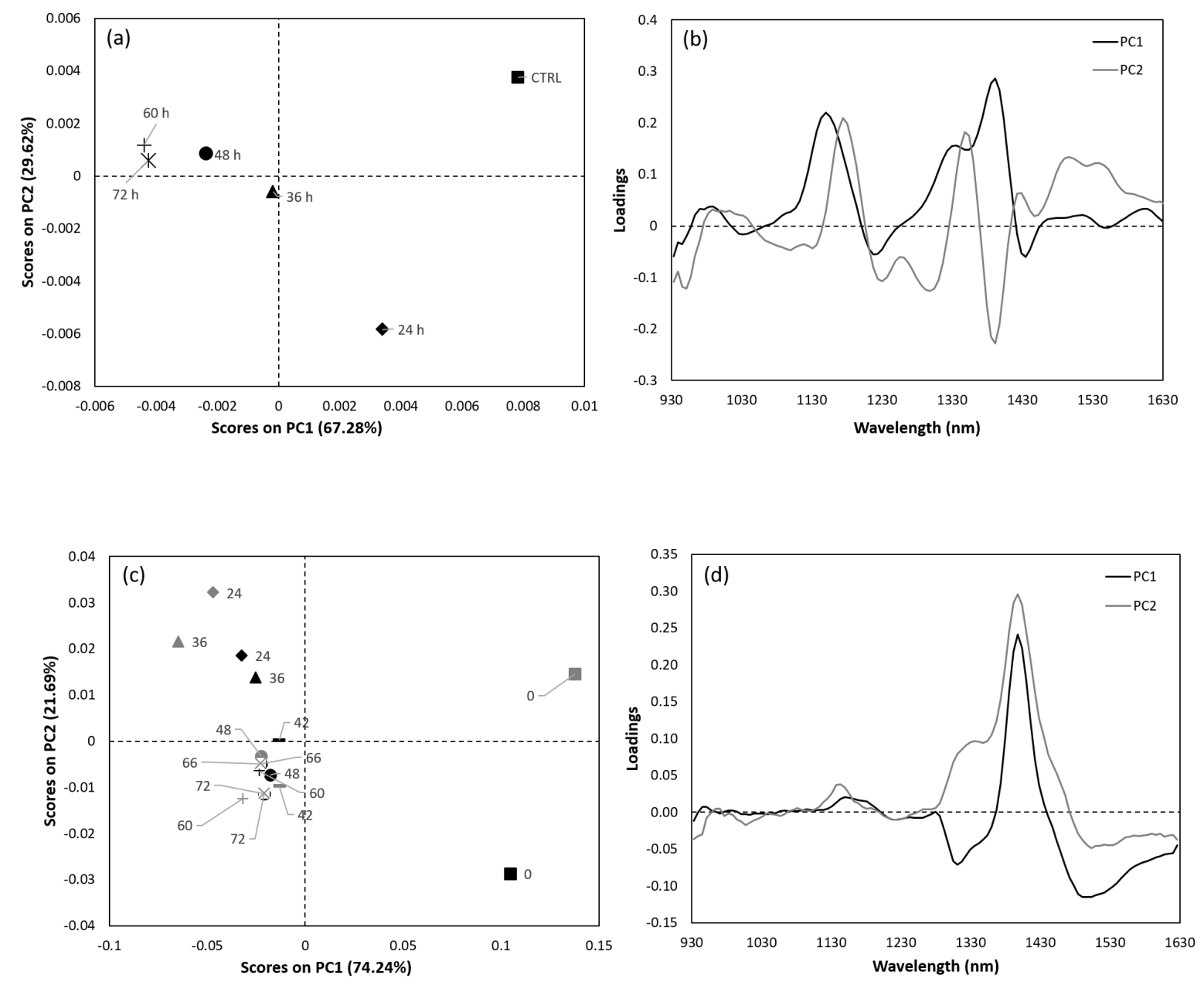

Figure 4. Principal Component Analysis on MicroNIR spectra collected on dried (a, b) and wet (c, d) sprouted grains at each sampling point (CTRL, 24h, 36h, 48h, 62h and 72h): (a, c) scores plot of PC1 and PC2; (b, d) loadings plot of PC1 and PC2. 

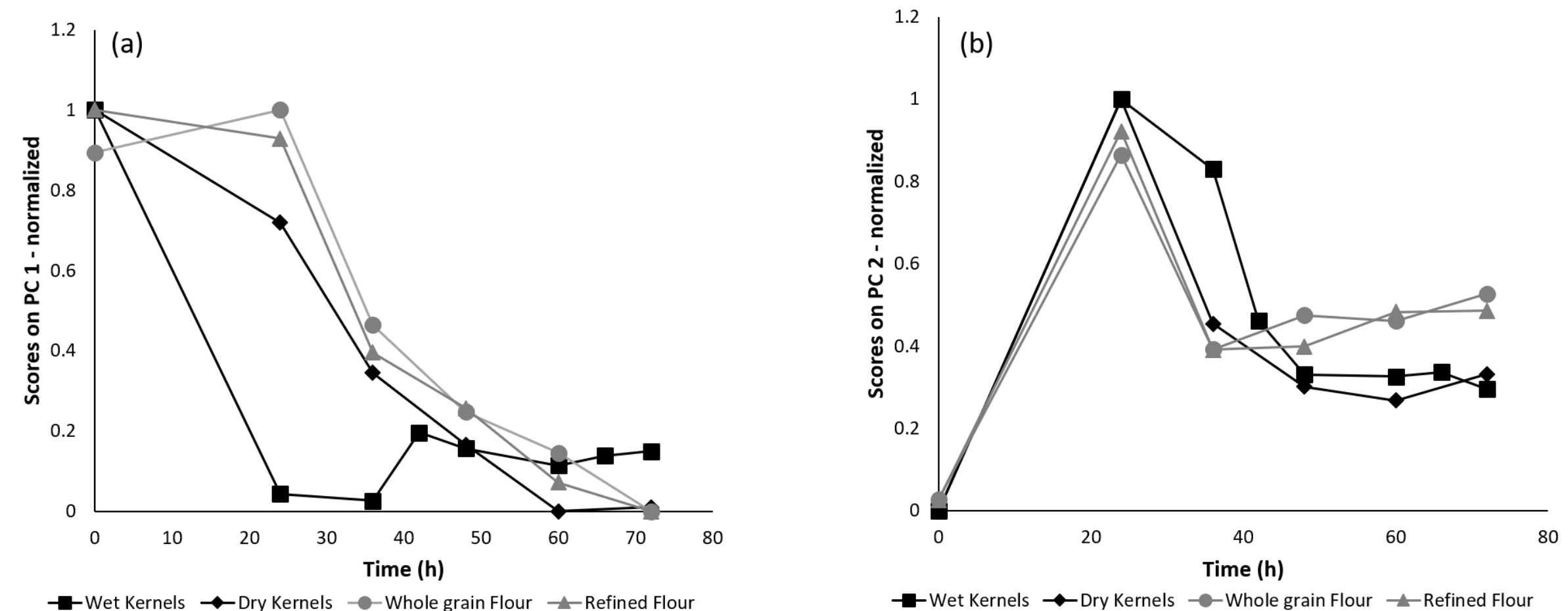

Figure 5. Normalised scores vs sprouting time obtained from Principal Component Analysis on MicroNIR data on wet kernels ( $\mathbf{a})$, MicroNIR data on dry kernels $(\bullet)$, data from composition, enzymatic activities, starch pasting properties and gluten aggregation kinetics of whole grain $(\bullet)$ and refined flour ( $\mathbf{\Delta}$ ): (a) PC1 scores vs sprouting time; (b) PC2 scores vs sprouting time. 